\title{
Theoretical Aspects of International Investment Projects
}

\author{
Olga Sokolova*, Nadezhda Goncharova, Valentina Lapina, Pavel Letov \\ Ural State University of Economics, Yekaterinburg, Russia \\ *Corresponding author. Email: olgalsokol@mail.ru.
}

\begin{abstract}
The gist of this article boils down to increasing the efficiency of the implementation of international investment projects in the Russian Federation. Difficulties in making a decision on investments for the implementation of international investment projects, difficulties in assessing their effectiveness and risk analysis indicate the urgency of the problem of financing and implementing international investment projects. The Russian market is characterized by such factors as low investment attractiveness, an undeveloped system of state regulation of issues related to the development, financing, implementation and evaluation of the effectiveness of international investment projects, significant gaps in the legislative framework. The article emphasizes that it is necessary to create a competent methodological base that answers key questions related to Russian international investment projects. The main hypothesis is based on the need to use international experience in assessing the effectiveness of bproject implementation and forecasting risks when making a decision on their financing. The main criteria for evaluating international investment projects were determined. The article presents the measures that determine the regulation of Russian international investment projects for future periods.
\end{abstract}

Keywords: international investment projects, project activity, investment activity, foreign investment, efficiency assessment, financing of investment projects, infrastructure projects.

\section{INTRODUCTION}

Investment projects of an international scale are a complex type of project activity based on complementary relationships and capabilities of partners, requiring significant investments of financial resources. Many scientists paid close attention to the theoretical aspects of international investment projects [1-10]. The specificity of the implementation of projects that go beyond the national borders of one state lies in the differences manifested in the economic, technological, political, social spheres of the countries participating in the projects [11].

Significant factors are the socio-economic indicators of the country: budgetary and tax policy, political situation, creditworthiness of banks, solvency of the population, inflation rate, labor productivity [12].

The purpose of this study is to study the principles of implementing international investment projects, analyze the features of assessing their effectiveness, study methods of their implementation, analyze international investment projects of the Russian Federation at the present stage, as well as identify problems and prospects for the implementation of international investment projects in the Russian Federation.

\section{MATERIALS AND METHODS}

The research base consists of legislative and other normative legal acts, textbooks, teaching aids and other theoretical materials of various authors as well as statistical and other materials.

The methodological basis of the study is formed by the regulatory legal acts of the Russian Federation, regulating the implementation of international investment projects of the Russian Federation, research materials of authoritative economists on the implementation and assessment of the effectiveness of international investment projects.

\section{RESULTS AND DISCUSSION}

In international practice, investment activities are carried out in the form of investment projects and programs. 
The concept of "project" has been used in international practice for more than ten years and, according to foreign methodology, means a set of interrelated activities designed to achieve the set goals in conditions of limited resources and time.

In accordance with the goals and objectives, the following types of projects are distinguished:

- commercial (aimed at achieving results);

- non-profit (aimed at solving the problem).

In addition, projects can be subdivided into other types, united by one or another feature (table 1) [13].

Today the task is to develop a mechanism for managing major reforms and targeted programs. Based on this separation logic, three classes of projects of various types and types can be distinguished.

Megaprojects are targeted programs or measures to reform the country's economy, containing many interrelated projects. They are united by a common goal, allocated resources and allotted time for their implementation. Megaprojects can be international, national, regional, intersectoral, sectoral and mixed. They have a number of distinctive features:

- high cost (over 1 billion US dollars) and, accordingly, labor intensity;

- the complexity of the organizational structure of management;

- duration (more than 5 years) and stages of implementation;

- the need to attract other countries;

- influence on the social and economic environment of a region, a group of regions or the country as a whole.

The specifics of megaprojects require a number of

Table 1. Types of international investment projects.

\begin{tabular}{|c|c|c|}
\hline Sign & Project type & Description of the project type \\
\hline \multirow{3}{*}{$\begin{array}{l}\text { by } \\
\text { investment } \\
\text { terms }\end{array}$} & long-term & projects that will take more than 5 years to complete (in some sources, more than 3 years) \\
\hline & mid-term & projects that will take from 3 to 5 years to complete (in some sources, from 1 to 3 years) \\
\hline & short term & projects that will take up to 3 years to complete (in some sources, up to 1 year) \\
\hline \multirow{4}{*}{$\begin{array}{l}\text { by } \\
\text { investment } \\
\text { object }\end{array}$} & intersectoral & projects regulating the most important macroeconomic proportions \\
\hline & $\begin{array}{l}\text { sectoral and } \\
\text { sectoral }\end{array}$ & projects aimed at solving problems of certain industries or sectors of the economy \\
\hline & regional & $\begin{array}{l}\text { projects containing a set of measures to influence the results of the project on the socio- } \\
\text { economic state of certain regions and regions }\end{array}$ \\
\hline & commodity & $\begin{array}{l}\text { projects that determine the mechanisms of production and market promotion of a particular } \\
\text { product }\end{array}$ \\
\hline \multirow[t]{4}{*}{ in scale } & global & $\begin{array}{l}\text { projects, the implementation of which significantly affects the economic, social or } \\
\text { environmental situation on Earth }\end{array}$ \\
\hline & large-scale & projects affecting the economic, social or environmental situation in only one country \\
\hline & $\begin{array}{l}\text { regional, city } \\
\text { (sectoral) scale }\end{array}$ & $\begin{array}{l}\text { projects, the implementation of which significantly affects the economic, social or } \\
\text { environmental situation in a particular region, city (industry) and does not significantly } \\
\text { affect the situation in other regions, cities (industries) }\end{array}$ \\
\hline & local & $\begin{array}{l}\text { projects, the implementation of which does not have a significant impact on the economic, } \\
\text { social and environmental situation in regions and / or cities, on the level and structure of } \\
\text { prices in commodity markets }\end{array}$ \\
\hline \multirow{3}{*}{$\begin{array}{l}\text { in terms of } \\
\text { alternative } \\
\text { choice of } \\
\text { the best } \\
\text { project }\end{array}$} & independent & $\begin{array}{l}\text { projects, the decision to implement one of which does not affect the decision to implement } \\
\text { the other }\end{array}$ \\
\hline & complementary & $\begin{array}{l}\text { projects that can be accepted or rejected at one time. Subdivided into: } \\
\text { complementary (when the adoption of one investment project leads to an increase in income } \\
\text { for other projects) and projects that are interconnected by a substitution relationship (the } \\
\text { adoption of a new project leads to a decrease in income for one or more existing projects) }\end{array}$ \\
\hline & $\begin{array}{l}\text { mutually } \\
\text { exclusive }\end{array}$ & $\begin{array}{l}\text { projects that cannot be implemented at the same time, i.e. the adoption of one of them } \\
\text { means that the remaining projects cannot be implemented }\end{array}$ \\
\hline \multirow[t]{3}{*}{$\begin{array}{l}\text { by } \\
\text { investment } \\
\text { volume }\end{array}$} & large & $\begin{array}{l}\text { projects with an investment of more than } 1,000,000 \text { US dollars. Large projects - projects of } \\
\text { large enterprises, which are based on a progressively "new idea" for the production of } \\
\text { products necessary to meet the demand in the domestic and foreign markets }\end{array}$ \\
\hline & average & $\begin{array}{l}\text { projects with an investment amount of up to USD 1,000,000. Medium projects are most } \\
\text { often projects of reconstruction and technical re-equipment of existing production facilities. } \\
\text { They are implemented in stages for individual industries in strict accordance with pre- } \\
\text { developed schedules for the receipt of all types of resources, including financial }\end{array}$ \\
\hline & small & $\begin{array}{l}\text { projects with an investment amount of up to USD } 100,000 \text {. Basically, small investment } \\
\text { projects represent plans to expand production and increase the range of products. They are } \\
\text { distinguished by relatively short implementation times. Small projects usually do not require } \\
\text { a special study of the feasibility study and related issues }\end{array}$ \\
\hline \multirow{2}{*}{$\begin{array}{l}\text { depending } \\
\text { on the } \\
\text { amount of } \\
\text { risk }\end{array}$} & $\begin{array}{l}\text { reliable risk- } \\
\text { free }\end{array}$ & $\begin{array}{l}\text { projects characterized by a high probability of obtaining a guaranteed result (for example, } \\
\text { projects carried out on a government order) }\end{array}$ \\
\hline & risky & $\begin{array}{l}\text { projects that are characterized by a high degree of uncertainty of both costs and results (for } \\
\text { example, projects related to the creation of new industries and technologies) }\end{array}$ \\
\hline
\end{tabular}


factors to be taken into account, namely:

- distribution of project elements to different performers and the need to coordinate their activities;

- the need to analyze the socio-economic environment of the region, the country as a whole, and possibly a number of countries participating in the project;

- the need to separate it as an independent phase of the development of the project concept;

- development and constant updating of the project plan;

- the need to perform the planning phase at all levels of plans: from strategic to operational, taking into account the probabilistic nature and risk of the project;

- the need to monitor the project with constant updating (updating) of all elements of the project plan;

- taking into account the uniqueness (uniqueness) of the megaproject.

Multiprojects are the interweaving of various interrelated subprojects in one project: economic, social, organizational, technical, as well as the presence of a multi-channel system of supply and sales of products, which makes it necessary to take into account the external environment of the project and carry out the socalled multi-criteria management.

Multiprojects involve changing existing or creating new organizations and firms. A multi-project is the fulfillment of many orders (projects) and services within the production program of one enterprise, limited by its production, financial, time capabilities and customer requirements.

Other examples of multi-projects can be cited:

- one contractor performs a set of works under separate contracts of different volumes for different customers;

- several contractors perform work on the complexes of one object for one customer;

- several contractors perform work under separate contracts for different customers in the same area.

And, finally, the most famous class of monoprojects in the past represents the solution of mainly one problem - at the enterprise level. From the experience of American practice, investments in such projects amount to no more than 10-15 million US dollars. Monoprojects allow a number of simplifications in the design and implementation procedure, in the formation of the project team.

For monoprojects, you can recommend:
- appoint one manager (coordination should be carried out by one person);

- flexible organization of the project team, ensuring the interchangeability of its members;

- the most simple form of the project schedule;

- clear knowledge of each team member of their tasks and scope of work;

- the start-up of the facility should be carried out by the same engineers who started work on the project.

Thus, capital is mainly concentrated in economically developed countries with high labor productivity. This is where a significant part of the financial capital of economically backward countries, their natural resources and talents comes in [14].

Having established the "start" and "end" of the project, you can define the next important concept associated with the project - the time interval between the moment the project appears and the moment it is liquidated, or the life cycle of the project.

The project life cycle is the starting point for investigating the problems of financing project work and making decisions about capital investments for implementation. According to the established tradition, the states through which the project passes are called phases (stages, stages). Due to the complexity of the implementation process in practice, it is difficult to formulate a universal approach to dividing this process into phases. In solving such a problem for themselves, the organizations participating in the work on the project can be guided by their role in the project, their experience and the specific conditions of the project. Therefore, in practice, the division of the project into phases can be very diverse. The main thing in the process of identifying phases and stages is to determine specific independent control points,

The implementation of the project requires the implementation of a certain set of activities: working out the possibilities of implementing the project, developing its foundations, describing its production facilities, contracting activities, organizing and financing project work, creating new technologies, planning resources and project progress, purchasing materials and equipment, and also construction and commissioning of finished objects, etc. [14].

The Russian Federation is implementing a number of international investment projects both on the territory of our country and abroad. The business nationwide analytical resource "Expert Online" has compiled a rating of the 10 largest investment projects in the Russian Federation until 2025 (Table 2).

It is necessary to consider the largest implemented, ongoing and unrealized international investment projects of the Russian Federation. 
One of the largest implemented international investment projects is the Power of Siberia gas trunkline.

Power of Siberia is a main gas pipeline for gas supplies from Yakutia to Primorsky Krai and the countries of the Asia-Pacific region. A joint project of Gazprom and CNPC (China), which was opened on December 2, 2019. The construction cost was initially estimated at 800 billion rubles, but was later revised to 1.1 trillion rubles [15].

The total cost of infrastructure projects related to the gas pipeline (in particular, field development, construction of a gas processing plant) is estimated at \$ 55 billion to $\$ 70$ billion.

It is planned that in 2020 at least 5 billion cubic meters of gas will be supplied to China, in 2021 - 10 billion, in 2022 - 15 billion cubic meters of gas, reaching the design capacity in 2025 [16].

At the beginning of March 2018, 1,580 kilometers of the gas pipeline were built [13]. As of March 21, 2018, 1,629.3 kilometers of the linear part of the gas pipeline or $75.5 \%$ of the section from the Chayandinskoye field to Blagoveshchensk were built [18]. As of May 17, $2018,1,791$ kilometers or $83 \%$ of the linear part of the gas pipeline section from the Chayandinskoye field to the border with China in the Amur Region were built [19].
On June 8, 2018, Gazprom announced the readiness of the linear part of the Power of Siberia gas pipeline section from the Chayandinskoye field to the border with China by $84.4 \%$ (more than 1,820 kilometers). The company also noted the successful completion of the drilling of the second tunnel under the Amur River on the border with China. The tunnel is a reserve line through which blue fuel will be exported to the PRC.

As of March 19, 2019, the bulk of the construction of the section from Yakutia to the Russian-Chinese border was completed on the Power of Siberia gas pipeline, construction and installation work was underway at the Atamanskaya border compressor station [20].

On July 23, 2019, the Russian and Chinese sections of the Power of Siberia gas pipeline docked at the border of the two countries. [21]

At the end of August 2019, work began to displace nitrogen and fill the cavity of the Power of Siberia gas pipeline with natural gas.

On December 2, 2019, the official commissioning of the gas pipeline took place, during a teleconference with the participation of President of the Russian Federation Vladimir Putin and Chairman of the People's Republic of China Xi Jinping [14].

The organizations "Greenpeace Russia" and the World Wildlife Fund (WWF) opposed the construction

Table 2. 10 largest investment projects in the Russian Federation until 2025.

\begin{tabular}{|c|c|c|c|c|}
\hline Industry / project & $\begin{array}{l}\text { Investor } \\
\text { (initiator) }\end{array}$ & $\begin{array}{l}\text { Implement } \\
\text { ation } \\
\text { period }\end{array}$ & $\begin{array}{l}\text { Invest } \\
\text { ments } \\
\text { (RUB } \\
\text { billion) }\end{array}$ & Implementation result \\
\hline $\begin{array}{c}\text { High-speed highway VSM Moscow- } \\
\text { Kazan (pilot section VSM-2 Moscow- } \\
\text { Yekaterinburg) }\end{array}$ & $\begin{array}{l}\text { Russian } \\
\text { Railways }\end{array}$ & after 2018 & 1,400 & $\begin{array}{l}\text { Halving the travel time between Moscow and } \\
\text { Kazan. Creation of a groundwork for the extension } \\
\text { of the highway to Yekaterinburg }\end{array}$ \\
\hline South Stream gas pipeline & Gazprom & $2015-2016$ & 1190 & $\begin{array}{c}\text { Creation of an alternative route for gas supplies to } \\
\text { Europe bypassing transit countries }\end{array}$ \\
\hline Trunk gas pipeline "Power of Siberia" & Gazprom & 2017 Nov. & 770 & $\begin{array}{l}\text { A gas pipeline with a length of about } 4,000 \mathrm{~km}, 61 \\
\text { billion cubic meters. meters of gas per year, } \\
\text { including } 38 \text { billion cubic meters. m - export to } \\
\text { China }\end{array}$ \\
\hline $\begin{array}{l}\text { Gas liquefaction plant "Yamal-LNG" } \\
\text { near the village of Sabetta }\end{array}$ & NovaTEK & $\begin{array}{l}2016 \text { (first } \\
\text { stage) }\end{array}$ & 680 & $\begin{array}{c}\text { Expansion of the geography of possible Russian } \\
\text { gas supplies }\end{array}$ \\
\hline $\begin{array}{l}\text { Development of the port of Ust-Luga } \\
\text { (Leningrad region) }\end{array}$ & $\begin{array}{l}\text { Ministry of } \\
\text { Transport of } \\
\text { the Russian } \\
\text { Federation }\end{array}$ & until 2025 & 630 & $\begin{array}{l}\text { Reducing dependence on exports from the ports of } \\
\text { the Baltic countries }\end{array}$ \\
\hline $\begin{array}{l}\text { Gas processing and helium complexes } \\
\text { (Belogorsk, Amur region) }\end{array}$ & Gazprom & after 2018 & 600 & $\begin{array}{c}\text { Creation of a gas processing plant with a capacity } \\
\text { of up to } 60 \text { billion cubic meters. m per year, } \\
\text { import substitution }\end{array}$ \\
\hline $\begin{array}{l}\text { High-speed highway Moscow-St. } \\
\text { Petersburg (M11) }\end{array}$ & $\begin{array}{c}\text { GC } \\
\text { "Avtodor" }\end{array}$ & 2018 Nov. & 550 & Development of the road and logistics network \\
\hline Gas liquefaction plant near Vladivostok & Gazprom & $2018-2020$ & 510 & $\begin{array}{l}\text { The plant's capacity is at least } 15 \text { million tons of } \\
\text { LNG per year. Expansion of the geography of } \\
\text { possible Russian gas supplies }\end{array}$ \\
\hline Vostochny Cosmodrome (Amur Region) & Roscosmos & Feb 2020 & 492 & $\begin{array}{l}\text { Possibility of launching manned spacecraft from } \\
\text { Russian territory }\end{array}$ \\
\hline $\begin{array}{c}\text { Kankunskaya HPP and a comprehensive } \\
\text { project for the development of South } \\
\text { Yakutia } \\
\end{array}$ & $\begin{array}{c}\text { The Republic } \\
\text { of Sakha } \\
\text { (Yakutia) }\end{array}$ & after 2020 & 492 & $\begin{array}{l}\text { Reducing the electricity shortage in the region, } \\
\text { diversifying the economy of Yakutia }\end{array}$ \\
\hline
\end{tabular}


of a gas pipeline in the park "Ukok Quiet Zone" in Altai. In a joint statement, environmentalists said that the planned Power of Siberia-2 pipeline (the so-called Western route) would disturb the fragile highmountainous soil and adversely affect the flora and fauna of the plateau [22].

It should be noted that according to the RussianAsian Union of Industrialists and Entrepreneurs (RASPP), today the Russian side is expected to increase the rate of oil, gas and liquefied natural gas exports thanks to the newly launched Power of Siberia and Yamal LNG projects [23].

Among the largest international investment projects of the Russian Federation, there are those that, for a number of reasons, were suspended or completely canceled. One of the key such projects is the South Stream gas pipeline.

Thus, after analyzing the situation with the implementation of the largest international investment projects in the Russian Federation, it can be concluded that even with significant investments and the study of all the risks that are possible in the implementation of investment projects, there is still the possibility of the impossibility of implementing the project. In the case of international investment projects, situations often occur in which problems arising for a backbone organization or even an entire state in the international arena can lead to significant losses and termination of the project.

\section{CONCLUSION}

Summing up, it should be noted that the Russian economy has made a huge step forward over several decades of development in accordance with the laws of the market. This is manifested not only in specific phenomena that are understandable only to researchers of the economic environment. This can also be seen in the expansion of the investment market. Today's projects attract the attention of not only Russians - often capital owners from Europe and Asia, the United States and other countries act as investors.

It is also important that in pursuance of the Decree of the President of the Russian Federation dated May 7, 2018 No. 204 "On national goals and strategic objectives of the development of the Russian Federation for the period up to 2024" 25 percent of their share in the gross domestic product, as well as to create conditions for their attraction [1].

Attraction of investments is also aimed at obtaining new technologies and $R \& D$ results (participation in joint $\mathrm{R} \& \mathrm{D}$, obtaining rights to key results of intellectual activity and creating our own results of intellectual activity), gaining access to foreign markets, creating new high-tech jobs and improving the qualifications of personnel. The result of the implementation of the task of attracting investment is the creation and modernization of domestic industries, built into the value added chains in the world market and having a scientific and technical groundwork for R\&D.

The most interesting are international investment projects implemented within the framework of RussianChinese cooperation.

Here are examples of the most ambitious investment cooperation between Russia and China:

- China State Electricity Grid Corporation injected US \$ 1.1 billion into Sintez Group of Companies, which transports and redistributes energy between lower-ranking power grid facilities;

- purchase of the already mentioned Chinese Investment Corporation shares of the Moscow Exchange. A 5.4\% stake was purchased, for which Chinese citizens paid a total of US \$ 100 million.

In addition, since 2009, there has been a Program of Cooperation between the PRC and the administrative units of the Far East and Eastern Siberia, during which 22 projects between China and Russia have already been transferred for direct investment.

The main principles for the development of RussianChinese investment cooperation, like any other, is to increase the available finances. And if this does not happen, then no investor wants to lose their money because of unknown ideals or following a Program that goes against their beliefs.

The main goals of the development of RussianChinese investment cooperation is making money. Only the investor has already earned them, so he is engaged in a thoughtful search for potentially profitable enterprises. This is not only about Russia. Chinese investors are now seen in all countries of the former USSR, in Europe, Latin America. Therefore, if the investment projects of Russia seem unattractive to businessmen from the PRC, they will quickly find another place for investing their own funds - in countries with a cultivated investment climate, a moderate, falling or zero level of corruption and highquality labor resources.

Not only Chinese, but also Russian businessmen have investment capital. Compatriots are interested in construction and transportation.

The dynamics are positive. If in 2006 only 67 million US dollars were invested in the economy of the PRC, then in 2014 this figure increased to 869 million US dollars. Here is a list of the most striking examples of this - reverse, investment cooperation:

- a plant in Shuanyashan, Heilongjiang province, which produces vanadium pentoxide, received US \$ 18 million from the Petropavlovsk Group of Companies; 
- Rusal Group of Companies invested USD 15 million in 2 enterprises for the production of cathode blocks for aluminum smelters. Location - Shanxi province;

- construction of an oil refinery in Tianjin, in which Rosneft has invested 5 billion US dollars. Unfortunately, the Chinese side did not allow the idea of direct investment to be implemented, selling only $49 \%$ of its shares.

- OJSC "Kuibyshev Azot" invested 8.1 million US dollars in the development and creation of construction plastics. True, 10 million was given to the enterprise by the He E trading company, registered in Shanghai, so the Russian side again did not receive a controlling stake;

- a very interesting project - the Energomera concern from the Stavropol Territory took part in the construction of an enterprise in Changzhou, specializing in the production of components for the manufacture of solar panels;

- the exception rather than the rule is the creation of the FescoLinesChinaCompany, which deals with logistics. The volume of investments of 1.56 million US dollars made it possible to create an investment facility with $100 \%$ Russian capital.

Thus, despite the existence in the Russian economy of not the most favorable conditions for the development of international investment projects, our country is confidently moving towards increasing cooperation with foreign countries. The problems existing in the economic system of our country are characteristic not only of Russia, but also of many developing and even developed countries of the world.

\section{REFERENCES}

[1] On national goals and strategic objectives of the development of the Russian Federation for the period up to 2024: Decree of the President of the Russian Federation of 07.05.2018, No 204. http://www.consultant.ru.

[2] G.F. Balakina, Specifics of Forming a Regional Socioeconomic Development Strategy in Context of Modernization. In: Regional Research of Russia, 5(3) (2015) pp. 270-275.

[3] E. Katherine, Kemsley, Marianne Defernez, Federico Marini, Multivariate statistics: Considerations and confidences in food authenticity problems. In: Food Control, 105 (2019) pp. 102-112.

[4] N. A Goncharova, N. V. Merzlyakova, Investigation of import substitution and expansion impact in Russian foreign economic practice by supply chain strategy. In: International Journal of
Supply Chain Management, 9(2) (2020) pp. 772778.

[5] Jason DeBacker, Bradley T. Heim, Anh Tran, Importing corruption culture from overseas: Evidence from corporate tax evasion in the United States. In: Journal of Financial Economics, 117(1) (2015) pp. 122-138.

[6] Joanne Swaffield, David Evans, Daniel Welch, Profit, reputation and 'doing the right thing': Convention theory and the problem of food waste in the UK retail sector. In: Geoforum, 89 (2018) pp. 43-51.

[7] Kowsar Yousefi, Mohammad Vesal, Hanifa Pilvar, Import tax evasion and avoidance: Evidence from Iran. The Quarterly Review of Economics and Finance, In press, corrected proof Available online 29 June, 2019.

[8] T. Zh. Solosichenko, N. A. Goncharova, N. V. Merzlyakova, Brand platform as an element of a company marketing strategy. In: International Journal of Supply Chain Management, 8(4) (2019) pp. 815-823.

[9] Niccolò Pisani, Arno Kourula, Ans Kolk and Renske Meijer, how global is international CSR research? Insights and recommendations from a systematic review. In: Journal of World Business, 52 (2017) pp. 591-614.

[10] L. Yintsze, features of evaluating the effectiveness of investment Russian-Chinese international projects, Economy and business: theory and practice (2019).

[11] International investment projects https://studme.org.

[12] The essence and significance of international investment projects. https://studme.org.

[13] 50 largest investment projects in Russia until 2025. https://expert.ru.

[14] Russia started gas supplies to China via the Power of Siberia gas pipeline. https://tass.ru.

[15] The actual cost of the "Power of Siberia" has exceeded one trillion rubles. https://www.interfax.ru.

[16] The volume of gas supplies to China through the Power of Siberia was named. https://rg.ru.

[17] Gazprom has built 1,580 kilometers of the Power of Siberia gas pipeline. https://ria.ru.

[18] The linear part of the Power of Siberia gas pipeline was built at $75.5 \%$. https: www.gazprom.ruu.

[19] More than $1790 \mathrm{~km}$ have been built $-83 \%$ of the Power of Siberia gas pipeline. https://www.gazprom.ru.

[20] The Board of Directors reviewed the status of implementation of the largest investment projects. https://www.gazprom.ru.

[21] Russia and China have connected sections of the Power of Siberia gas pipeline. https://dprom.online. 
[22] The supply of Russian gas to China through Altai has an environmental problem. https://vz.ru.

[23] The growth of imports from the Russian Federation to the PRC has proved the effectiveness of the teamwork of Moscow and Beijing. https://rueconomics.ru. 